\title{
Sigurd Ore-Mineralization in West-Spitsbergen Island, Svalbard Archipelago
}

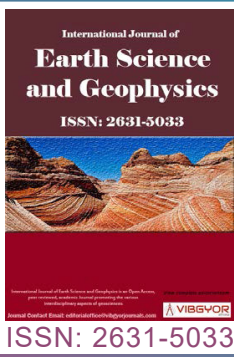

\section{AN Evdokimov*}

Geological \& Mineral Sciences, Saint-Petersburg Mining University, St Petersburg, Russia

\begin{abstract}
One of the largest silver-copper mineralization of the Mount Sigurdfjellet in Western Spitsbergen Island of the archipelago was discovered in 1990 by Russian geologists. The ore genesis is exclusively related to hydrothermal migration of ore substances from the enclosing sandstones and siltstones of the Devonian age. The subsequent study of the ore minerals, host rocks and basement rocks provided new insights on the geochemical characteristics of potential sources of metals and for new mineral occurrence - gold mineralization. The similarity of geochemical patterns of the Sigurd ore occurrence with that of the nearby upper Proterozoic marble may suggest that the latter is likely to be the source of ore substances and the second possible source related to the carbonate-containing streaks of the Low Devonian sediments. Ore-formation, probably due to repeated hydrothermal processes was completed in a period of tectonomagmatic activity in Jurassic-Cretaceous time.
\end{abstract}

\section{Keywords}

Svalbard, Sigurd, Copper, Silver, Gold, Geochemistry

\section{Introduction}

The Arctic islands represent ledges of continental crust exposed on the sea surfaces. Svalbard archipelago which is located on the northwestern frame of the Barents Sea is a prominent example. One of the early studies was conducted by our team in the 1990's in the north of the central part of West Spitsbergen Island (Figure 1). The region is characterized by ore-occurrence of copper and silver mineralization [1]. It is situated on the southern slope of Mount Sigurdfjellet. Sigurd is characterized by excess altitude of 400 to $900 \mathrm{~m}$ above mean sea level and is the largest of all islands found on the Svalbard archipelago.

As a result of continuous exploration of the ter- ritory, the total estimated resources of metals provide grounds to conclude the existence of deposits with industrial viability; subjected however, to further studies [2].

It was necessary to execute more detailed study of the geological structure, patterns of ore distribution, mineralogical composition and geochemical features and also to define geological and industrial type of mineralization, for localization of the source of substance of "Sigurd" ore-occurrence.

\section{Geological Structure of Sigurd Ore-Occur- rence}

The Sigurd ore-occurrence is located along the sub-meridian zone of the Breibogen fracture. This

\footnotetext{
*Corresponding author: AN Evdokimov, Dr. of Geological \& Mineral Sciences, Saint-Petersburg Mining University, St Petersburg, Russia

Accepted: December 14, 2020; Published: December 16, 2020

Copyright: (C) 2020 Evdokimov AN. This is an open-access article distributed under the terms of the Creative Commons Attribution License, which permits unrestricted use, distribution, and reproduction in any medium, provided the original author and source are credited.

Evdokimov. Int J Earth Sci Geophys 2020, 6:039
}

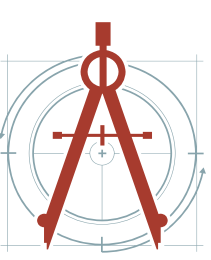




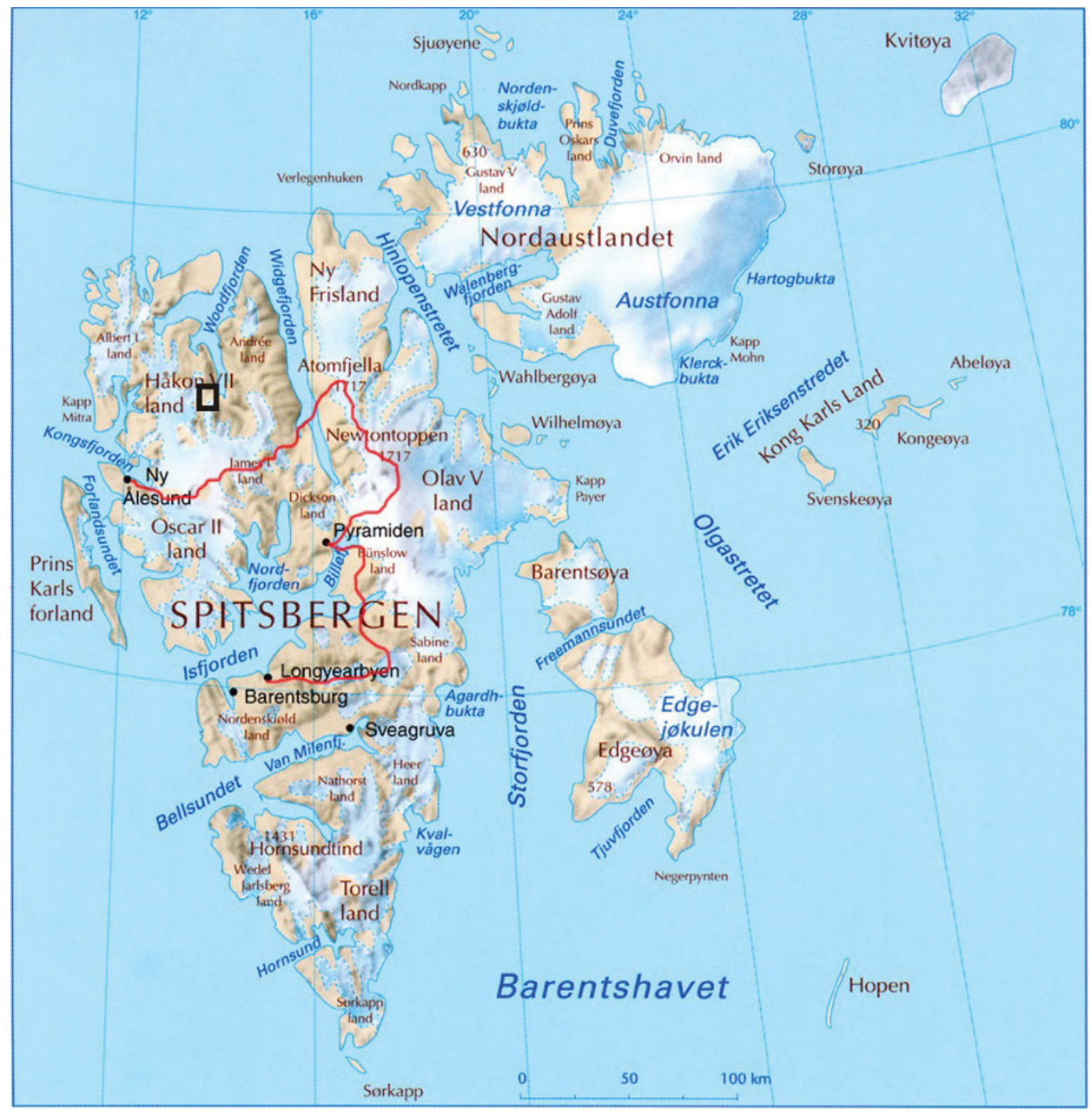

Figure 1: Svalbard archipelago and Sigurd ore-occurrence.

zone is framing the western flank of large graben structure of ore manifestation. The graben formation was caused by the Caledonian tectonic events; during which similar rift structure has been filled with conglomerates, sandstones, aleurolites and thin carbonate deposits. The Russian geological mapping of this site on the Western Spitsbergen Island have allowed us to find some more small ore-occurrences of sulfides of copper and lead, barite, fluorite, rhinestone. These discoveries has in turn led to the identification of metallogenic zones with a number of ore deposits within terrigenous deposits of the Devonian age and rocks of crystal basement framing the latter graben [3].

The upper-Proterozoic crystal slates and marble are confined to the western flank of Sigurd ore-oc- currence. The central and eastern parts are characteristically comprised of terrigenous complexes of Early-Devonian sandstones and aleurolites with interlayers of carbonates (Figure 2). The tectonic contact between Proterozoic and Devonian deposits is composed of fragmentary carbonates and brecciated formations.

It is important to note, that the ore mineralization is generally confined to tectonic fractures and veins cross-cutting carbonate interlayers in the Devonian sandstone unit. The distribution and migration of ore substances proceeds along the bedding of the carbonate strata. This suggests that the carbonate interlayers serve as geochemical barriers of ore hydrothermal solutions.

In Neogene period, layers of basalts were creat- 


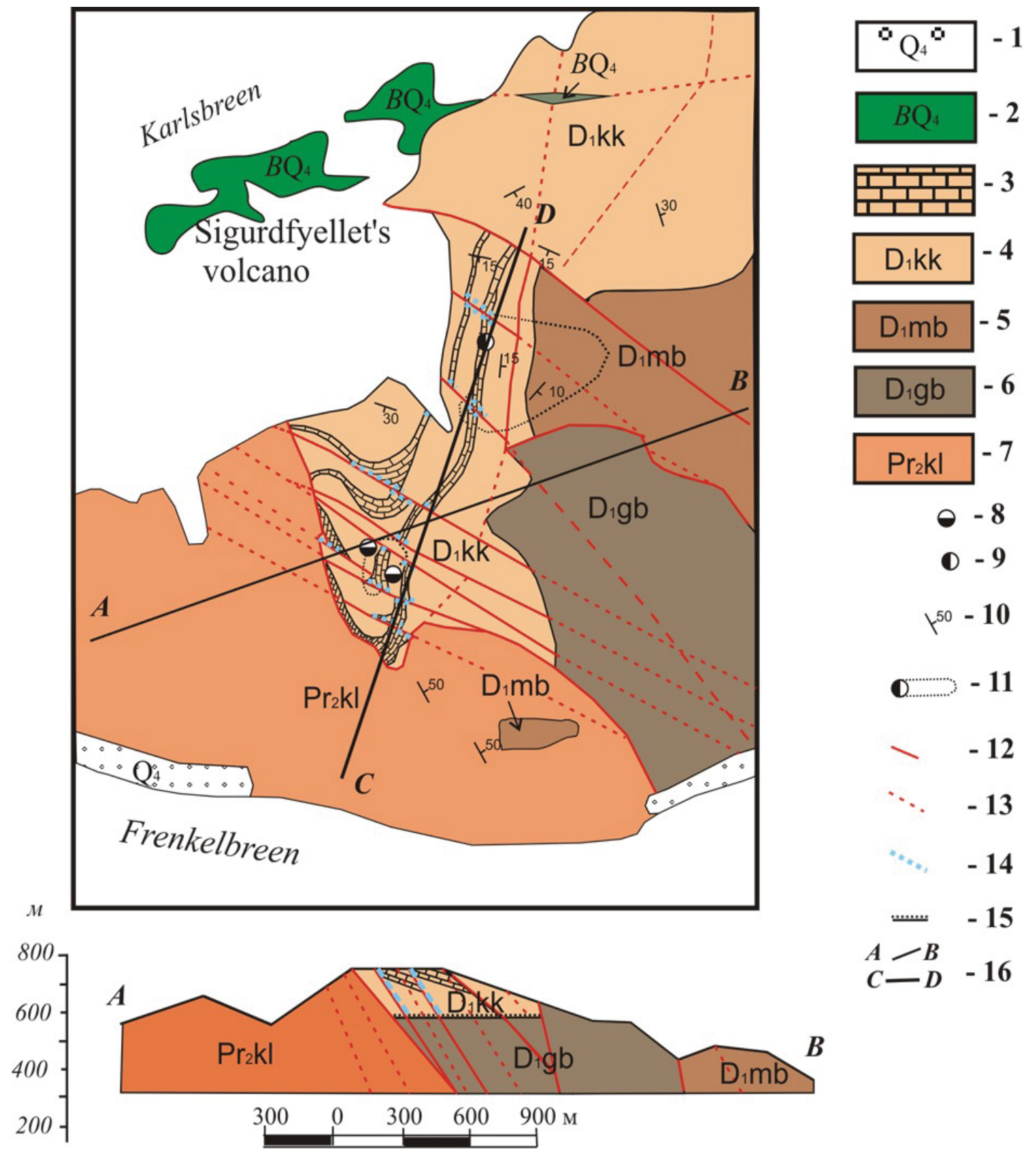

Figure 2: Schematic representation of the geological structure of Sigurd Silver-copper ore-occurrence, where: 1: Modern thin glacial deposits of Frenkelbreen and Vonbreen $\left(Q_{4}\right) ; 2$ : Alkaline olivine basalts of a Quaternary age (Mount Sigurdf'ellet volcano - $Q_{4 \beta}$ ); 3 : Green colored carbonaceous interbeds in the Devonian terrigenous deposits; 4: Red colored sandstones, aleurolites with gray-green interlayers of limestones of the Early Devonian age, Kap-Kyeldsen subsuite of Vud-bay series $\left(D_{1 k \mathrm{k}}\right)$; 5 : Sandstones and conglomerates of the Early Devonian age, Monakobreen, red-bay series of the Lower Devon $\left(\mathrm{D} 1_{\mathrm{mb}}\right)$; 6: Polymictic conglomeratic strata of the Germaniyabekken, the Lower Devonian $\left(D_{1 g b}\right)$; 7 : Marble and crystal slates of the Krossfyord series, Kollerbreen suite $\left(\operatorname{Pr}_{2 k}\right)$; 8: Copper mineralization in bed rocks; 9: Lead-copper mineralization in deluvial deposit; 10: Occurrence of geological strata; 11: Dispersion halos of copper-silver mineralization; 12: Established tectonic disturbance; 13: Inferred faults; 14: Manifestations of vein mineralization; 15: Geological boundaries of discordant bedding; 16: Geological and geochemical profiles across lines: AB: Geological and CD - geochemical.

ed in close proximity to the ore-occurrence; however the genetic linkage of this mineralization with Neogene volcanism is very unlikely.
In the Quaternary period the magmatic veins and dykes of alkaline-olivine basaltic composition which constitutes Mount Sigurdfjellet were 
formed. This represents the most southern flank of the four volcanic centers on the archipelago. Based on the estimates of various authors; eruption of volcanoes of Spitsbergen occurred within the last 10 thousand years [4]. Currently, only hydrothermal springs located several kilometers to the north of Mount Sigurdfjellet near Sverrefyellet's volcano on the seashore of Bokk-fyord are still active. The geological bases on the influence of Quarternary volcanism on the formation of ore substance remain equivocal.

The Sigurd ore-occurrence is represented by a series of the veins which cross-cut into terrigenous Devonian deposits and carries sulfides of copper and lead: Fahlore ores, chalcopyrite, galena in association with a barite mineralization. The main vein minerals are calcite, quartz, dolomite and magnetite. The evidence of ore veins cross-cutting the Low Devonian layers, suggest that the ore formation occurred much later in the post-Early Devonian time. However, the identification of sulphidic mineralization in Precambrian metamorphic rocks of the archipelago by Flud in 1969 [5] may be suggestive of pre-Devonian stage of ore genesis in similar veins caused by the Caledonian tectonic activity.

Authors of the Spitsbergen chapter in the monograph devoted to Solid minerals of the Arctic Islands of Eurasia [2] did not exclude the probability of the beginning of copper-sulphidic mineralization in the Early-Riphean time in the western part of Lifde-fjord, Bokk-fjord and Wood fjord where the group shows copper mineralization connected with the stratified bodies of Early-Riphean metamorphic rocks in the Amphibolitic facies.

\section{Methodology of the Study Ore Material}

Field studies of the southern spurs of Mount Sigurdfjellet in the area of the outlet to the surface of the vein zone with ore mineralization were carried out in three stages. At the first stage, the entire mineralization area, which is marked by deposits of rubbles and fragments of azurite, malachite, barite and galena, was divided using a measuring tape into a series of profiles with a $5 \mathrm{~m}$ interval between profiles. The profiles were oriented along the strike of the ore zone in the direction of $20^{\circ} \mathrm{NE}$. In every 5 $m$ interval within the profiles, ore sampling points were identified, which were marked with small rounds of local red-colored sandstones.

At the second stage, around each traverse within a radius of 2 meters, the outcrops of carbonate and sand deposits were studied in order to detect ore mineralization or crustal products of ore oxidation. The points of identified mineralization were placed on a large-scale plan with the designation of areas of vein mineralization and products of the weathering crust.

At the third stage of field work, samples from the identified areas of ore mineralization were collected and analyzed. Samples weighing up to 100150 grams were tested for subsequent quantitative spectral analysis and absolute dating of galena samples based on the ratio of lead isotopes in them.

Analytical work on the collected samples from the Sigurd ore occurrence was performed in the laboratories at Russian Geological Institute in St. Petersburg. This allowed us to create a correlation matrix between the contents of ore components and present a sub-vertical geochemical section of the ore occurrence. This was a newly performed study in this region.

As a result of testing on the network, it was possible to establish the presence of a classical zoning characteristic of the stock-type hydrothermal ore mineralization, the features of which are shown on Figure 3.

\section{Results and Discussion}

\section{Geological age of ore formation}

Analyses of isotopic composition of sulfur from the Sigalstad sulfides have indicated that the inclusions of hydrogen sulfide $\left(\mathrm{H}_{2} \mathrm{~S}\right)$ in the ore sulfides at the Mount Sigurdfjellet in the Western Spitsbergen Island and the Island Bearnow have equally low content of sulfur (34) isotope, as in the evaporates of the Permian age $[6,7]$. Hjelle [8] presented the estimated age of the ore-occurrence on the western coast of Spitsbergen to be approximately Tertiary. Isotopic ratios of lead from the galena samples in our early collections pointed to late Triassic age $(210 \pm 10)$ [1]. Taking into consideration the errors associated with the isotopic method used, it is therefore feasible to conclude that the ages reflect and/or confirm the Early-Devonian period of ore formation at the Mount Sigurdfjellet. A tectano-magmatic event with which the paragenetic sequence of hydrothermal activities which contributed to ore-mineralization is probably the intrusive dykes of the alkaline and ultrabasic rocks of the Svalbard in $\mathrm{D}_{3}-\mathrm{C}_{1}$ time.

Thus the age of sulphudic vein mineralization 


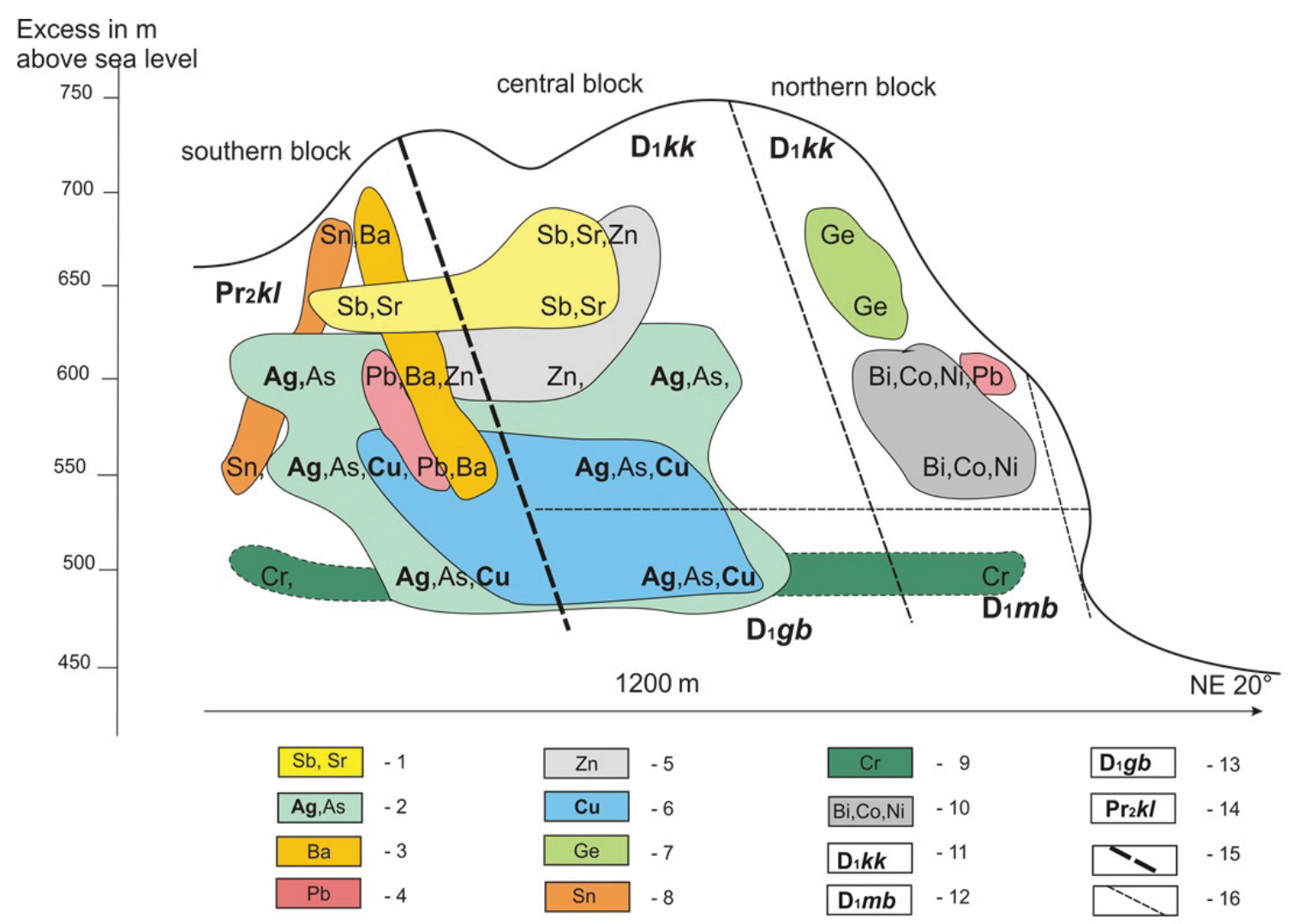

Figure 3: Oxidation zone minerals: $\mathrm{Cu}_{3}\left(\mathrm{CO}_{3}\right)_{2}(\mathrm{OH})_{2}$ azurite - blue and $\mathrm{Cu}_{2} \mathrm{CO}_{3}(\mathrm{OH})_{2}$ malachite - green one.

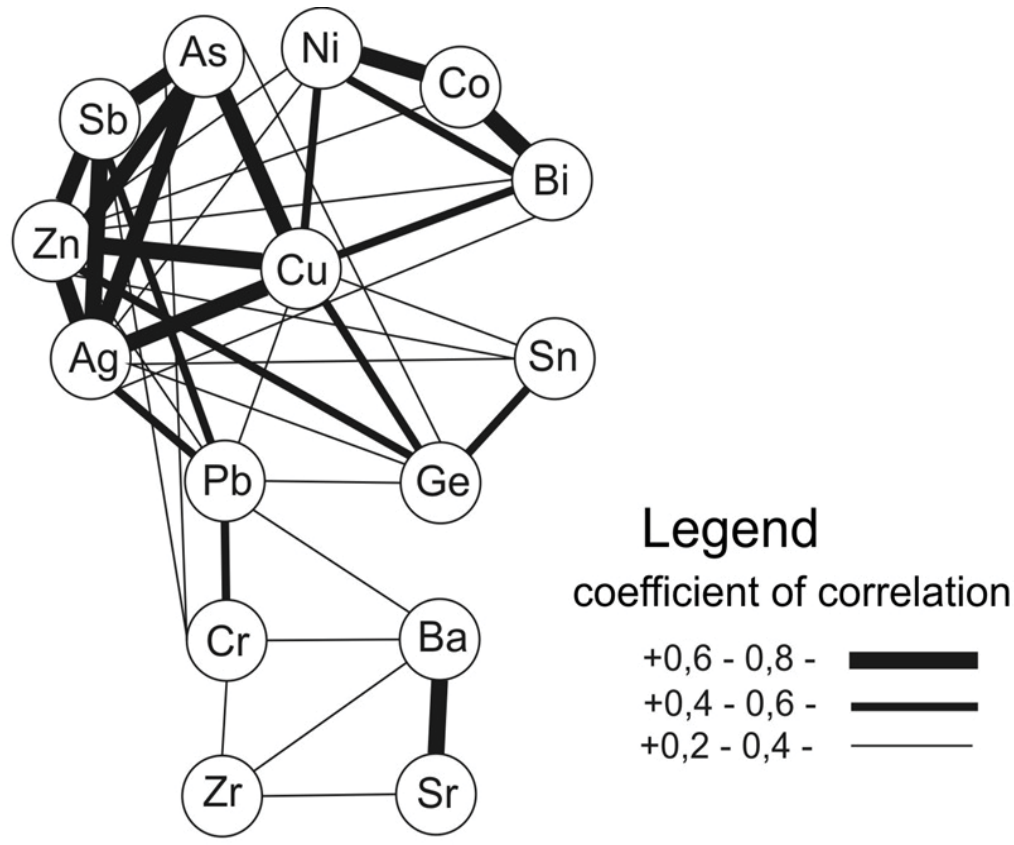

Figure 4: Geochemical zonality of the Sigurd ore-occurrence on a vertical $\left(0^{\circ}\right)$ and acute $\left(20^{\circ}\right)$ directions, where the anomalous concentrations are given by: 1: Antimony (Sb) and strontium ( $\mathrm{Sr}$ ); 2: Silver (Ag) and arsenic (As); 3: Barium (Ba); 4: Lead (Pb); 5: Zinc (Zn); 6: Copper (Cu); 7: Germanium (Ge); 8: Tin (Sn); 9: Chrome (Cr); 10: Bismuth (Bi), cobalt (Co) and nickel (Ni); 11: Sandstones and limestones of the Lower-Devonian Kap-Kyeldsen suite; 12: Sandstones and aleurolites of the Monakobreen suite, the Red-Bey series of the Lower-Devonian; 13: Polymictic conglomeratic strata of the Germaniyabekken, the Lower Devonian; 14: Marble and crystal slates of the Krossfyord series, Kollerbreen suite of the Upper Proterozoic; 15: A deep Breibogen fault - tectonic contact between Proterozoic and Devonian deposits; 16: Tectonic dislocations in the Devonian strata. 
on the Archipelago is estimated by a wide variety of ideas, beginning from the early-Riphean to the late-Paleozoic [1]. However, the age of the Sigurd ore-occurrence is constrained at Devonian. Geological studies of the Devonian graben zones of the West Spitsbergen indicate middle-late Devonian time as a time interval of ore formation.

\section{Correlation between macro and micro-com- ponents of ore}

Correlations between macro-and micro-components of the ore substances reflect schemes of isomorphism in crystal lattices of ore minerals, their paragenetic associations and secondary alterations. The correlation analysis has been made on a group of 53 ore samples and also the host rocks. The results are given in the classification scheme in Figure 4.

The strong correlations amongst elements are shown by thicker lines. On the above scheme, six element associations are distinctly visible: $\mathrm{Cu}, \mathrm{As}$, $\mathrm{Ag}, \mathrm{Sb}, \mathrm{Zn}$ and $\mathrm{Pb}$. Their strong correlation may be ascribed to the prevalence of copper-Arsenic -bearing ore minerals such as tennantite. Tennantite is a copper and arsenic sulfosalt mineral- $\mathrm{Cu}_{12} \mathrm{As}_{3} \mathrm{~S}_{13}$ with impurities of $\mathrm{Sb}, \mathrm{Bi}, \mathrm{Fe}, \mathrm{Zn}, \mathrm{Ag}, \mathrm{Hg}, \mathrm{Co}, \mathrm{Pb}$. The relationship of ore minerals in polished sections have shown that tennantite occurring in association with chalcopyrite $\left(\mathrm{CuFeS}_{2}\right)$, pyrite $\left(\mathrm{FeS}_{2}\right)$, galena (PbS) and sphalerite ( $\mathrm{ZnS}$ ) was formed at the earliest stage of mineral genesis. As a result of these associations, strong correlations between the listed elements were then formed. Most of the ore occurrence formed primarily in hypogene mineral complex.

The remaining element correlations are either reflective of a wide mineral occurrence across the area. Elemental association characterized by $\mathrm{Ba}-\mathrm{Sr}$ $\mathrm{Zr}-\mathrm{Cr}-\mathrm{Pb}$ was also noticed a characteristic of baritic veins $\left(\mathrm{BaSO}_{4}\right)$ and the accompanying mineralization, including an argentiferous galena, celestine $\left(\mathrm{SrSO}_{4}\right)$. Zirconium and chrome isomorphically replace cations of these minerals. Baritic and carbonate veins with galena as a rule settles out mainly at the top sections of the ore occurrence which is generally in coordination with the regularity of geochemical zonality in hydrothermal deposits.

In general, it is worth noting that the weak correlation between $\mathrm{Cu}$ and $\mathrm{Pb}$ is a characteristic of all ore-occurrences along the Devonian graben zone. This reflects the existence of either two or more stages of ore-formation in which these elements might have played variety of roles. In addition, the weak correlation reflected between $\mathrm{Cu}$ and $\mathrm{Ba}$ indicates barite formation separately from silver and copper; and may have been formed later together with fluorite.

The third association forms group of four elements: $\mathrm{Ni}, \mathrm{Co}, \mathrm{Bi}$ and $\mathrm{Cu}$. The strong correlations between these elements ( $\mathrm{Ni}$ and $\mathrm{Co}, \mathrm{Bi}$ and $\mathrm{Cu}$ ) is likely to be connected to the concentration of chalcocite $\left(\mathrm{Cu}_{2} \mathrm{~S}\right)$ replaced by covellite (CuS). Isomorphic impurity elements in chalcocite include: $\mathrm{Ag}, \mathrm{Co}, \mathrm{Ni}, \mathrm{As}$ and $\mathrm{Au}$. This association occupies the lowermost level in the vertical zonality of hydrothermal minerogenesis established by V. Emmons and S.S. Smirnov $[9,10]$.

The fourth association is represented by positive correlations between concentrations of: $\mathrm{Zn}, \mathrm{Ge}, \mathrm{Cu}$ and $\mathrm{Sn}$. Germanium occurs as a constituent in most silicate minerals and as isomorphic impurity in sphalerite up to $1000 \mathrm{~g} / \mathrm{t}$ in most cases. There are tin sulphides - $\mathrm{SnS}$ and $\mathrm{SnS}_{2}$ which naturally occur in association with $\mathrm{Cu}$ and $\mathrm{Zn}$ in the form of $\mathrm{Cu}, \mathrm{Zn}$ and Sn sulphides: Kesterite $\left(\mathrm{Cu}_{2} \mathrm{ZnSnS}_{4}\right)$. This association is relative to initial occurrence of tennantite and the later stage of paragenetic transformation of sphalerite to chalcopyrite.

\section{Paragenetic sequence of ore mineral crystal- lization}

Based on the structural relationship of ore minerals in polished sections from various sites of Sigurd ore occurrence and positive correlations between base elements, a sequence of crystallization of ore minerals was established:

Firstly, there was crystallization of fahlore ores associated with chalcopyrite, sphalerite and galena. In the second stage, bornitic ores with subordinate amount of pyrite, chalcopyrite and chalcocite were significantly formed. The third paragenetic stage of ore minerals was characterized by chalcocite, chalcocite-covellite of secondary sulfudic enrichment where chalcocite is replaced by covellite. The fourth stage does not have a strict time reference relative to the first three, since in different parts of the ore occurrence, especially close to marble of the Riphean age, barite veins are formed, and to a lesser extent celestine and calcite, cutting the veins of interspersed ores of all the first three paragenetic stages. The fifth and final stage of ore generation is represented by the zone of oxidation expressed 


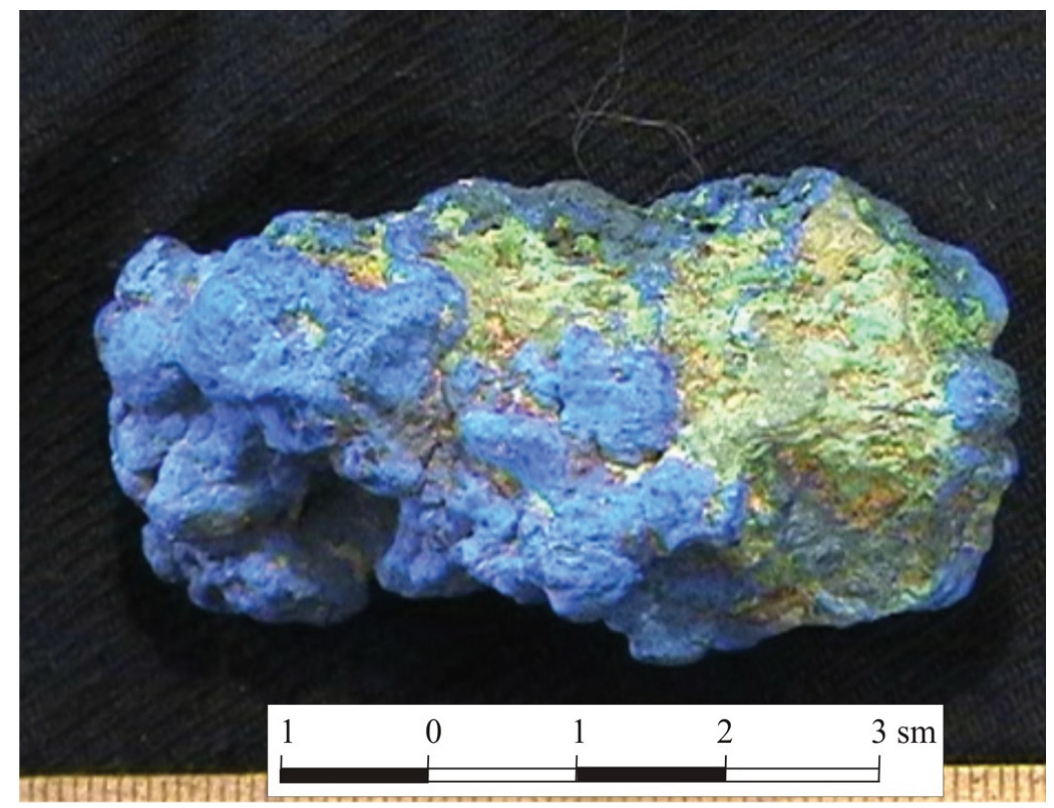

Figure 5: The scheme of positive correlative connections between macro- and micro-elements of Sigurd oreoccurrence.

by the formation of azurite $\left[\mathrm{Cu}_{3}\left(\mathrm{CO}_{3}\right)_{2}(\mathrm{OH})_{2}\right]$ and malachite $\left[\mathrm{Cu}_{2} \mathrm{CO}_{3}(\mathrm{OH})_{2}\right]$ respectively (Figure 5). There is also a manifestation of limonite $\left(\mathrm{Fe}_{2} \mathrm{O}_{3} \mathrm{xn}\right.$ $\mathrm{H}_{2} \mathrm{O}$ ) which develops on pyrite and chalcopyrite in an oxidation zone.

The greatest coefficient of concentration in the Sigurd ore occurrence given by silver $=218$. The maximum estimated grade using semi-quantitative spectral analysis is 500 and $617 \mathrm{~g} / \mathrm{t}$ and with the use of atomic and issue spectroscopy is $450.6 \mathrm{~g} / \mathrm{t}$. A continuous strong correlation between copper and silver in all is noted in all geochemical groups. The largest amount of silver is revealed in bournonite ( $\mathrm{PbCuSbS}_{3}$ )-3920 g/t, less in galena (PbS)-1940 $\mathrm{g} / \mathrm{t}$ and in fahlore ores $\left(\mathrm{Cu}_{12}(\mathrm{AsSb})_{4} \mathrm{~S}_{13}\right)$, bornite $\left(\mathrm{Cu}_{5} \mathrm{FeS}_{4}\right)$ and $\mathrm{Cu}_{2} \mathrm{~S}$ chalcocite from 488 to $1900 \mathrm{~g} / \mathrm{t}$. The average content of silver and copper has been calculated in accordance with analytical works carried out over the years and taking into account shortcoming which arises from different types of analyses such as spectral semi-quantitative and atomic. The average concentrations of $\mathrm{Ag}=124.9$ $\mathrm{g} / \mathrm{t}, \mathrm{Cu}=2.87 \%$.

\section{Geological and industrial type of mineraliza- tion}

The Sigurd ore occurrence was assigned [3] to the sulfide-polymetallic geological industrial type for a number of features [3]. The typical analogs are the ore deposits in Altai and Kazakhstan: Oryol, Irtysh, Maikhan and others. Characteristic features of geologic and industrial ore types are:

a) Confinement to the steeply dipping shearand lineament zones connected to deep faults.

b) Localization of large discontinuous deformations in the rear sides.

c) Contrast-containing complexes (metamorphic, igneous and sedimentary).

d) Early-ore formation from hydrothermalmetasomatic alteration of rocks and three subsequent stages: Chalcopyrite, with the formation of pyrite, chalcopyrite, sphalerite and rarely galena; the second-polymetallic with barite, carbonates, chalcopyrite, pyrite, galena and fahlore ores; the third vein quartz - sulfide or barite-polymetallic ore formation. Most of these features of the geological structure, mineral composition, and sequence of formation were revealed in the Sigurd ore occurrence.

Emmons [10] associated ore mineral paragenetic zones with temperature conditions. This however, went through a criticism mostly by Smirnov who suggested ore formation from hydrothermal fluids carrying ore substances from the areal intrusive complexes [9]. An example of a number of deposits, where the following sequence of element concentrations in halos from the supra-ore to subore is established: $\mathrm{Sb}-\mathrm{As}-\mathrm{Ba}-\mathrm{Ag}-\mathrm{Pb}-\mathrm{Zn}-\mathrm{Cu}-\mathrm{Bi}-\mathrm{Sn}$ -Co-Ni. 
The irregular testing network of the Sigurd ore occurrence due to the complexity of the mountainous terrain where the slope angle ranges from 20 to $80^{\circ}$ was calculated in regular accordance with the Surfer program and designed on a vertical plane oriented along an azimuth of 20 degrees NE. As a result a pictorial form indicating the distribution of anomalous content of ore elements in the altitude ranging from 450 to $700 \mathrm{~m}$ above mean sea level was obtained (Figure 3).

The cross-section consists of three blocks/compartments separated by tectonic faults. The southern block constitutes of crystal slates and marbles of the basement. It is intersected by series of ore-bearing veins and is separated from the central block by Breibogen fault zone oriented at an azimuth of $330^{\circ} \mathrm{NW}$. The Central block is composed of sandstones, aleurolites, and carbonate interlayers of the Lower Devonian Kap-Kyeldsen suite. The main ore substance is associated with carbonate layers and brecciated zones. The northern block forms part of the terrigenous and carbonates deposits of the Lower-Devonian and consist of a series of small ore-bearing veins (cm thick), occurring at the periphery of the ore occurrence.

The results of spectral semi-quantitative analysis carried out over the years, as well as X-ray fluorescence analysis of 270 samples, showed a good degree of convergence, which made it possible to use them to create trend distribution surfaces of major and minor ore elements in the section plane oriented at $20^{\circ}$ direction NE. A subsequent comparison of the positions of the maximum content of the analyzed elements was made according to the generalizing scheme shown in Figure 3.

\section{Geochemical zonality of Sigurd ore occurrence}

Figure 3 shows a common large copper-containing zone located in the lower part of the southern Precambrian and central Devonian blocks, marked in blue. This is the core of a larger anomalous zone containing copper, silver, and arsenic. The zone underlying the silver-copper anomaly is rich in chromium, which is associated with the occurrence of a deep fault zone. Chromium enrichment is noted in both basement rocks and Devonian rocks, indicating a probable deep source of ore substances. The migration of these ore substances from those deeper zones may have been facilitated by faulting, fracture zones and subsequent development of mélange-type dislocations at an angle of $50-70^{\circ}$ along the fracture zones to the Breibogen fault in the north easterly direction.

The existence of the chromium anomaly may also be due to a generally high chromium content in the entire terrigenous sequence of red-colored sandstones with heavy chromium minerals: chromium spinel, chromium diopside, and olivine - the product of alteration of ultramafic rocks located as thin dikes on the southern extension of the Breibogen fault zone in Ekmanfjord [11]. The chromium anomaly was recorded during earlier geological mapping in a deep fault zone on the Eastern flank of the Devonian Graben, near the Pyramid mine, in the Mimerdallen valley, where the upper Devonian layers outcrops. They contain an increased concentration of minerals of the heavy fraction of ultramafic paragenesis. In addition, it is impossible to exclude the imposed nature of the chrome anomaly caused by post-magmatic processes of mineral redistribution of Quaternary volcanic rocks.

Anomalies in the content of bismuth, cobalt, and Nickel in the base of the ore zone of the northern block of the Sigurd ore occurrence occupy a special position. It is marked in gray on the diagram. This association of elements is largely due to the chalcocite type of mineralization and, to a lesser extent, chalcopyrite, pyrite, and tennantite $\left(\mathrm{Cu}_{12} \mathrm{As}_{4} \mathrm{~S}_{13}\right)$.

Chromium, Nickel, and cobalt anomalies are characteristic of the subsurface hydrothermal copper deposits. Here, in the northern block, these anomalies can be caused by a sufficiently large distance from the deep fault zone, since they are concentrated sub-parallel to the Breibogen fault zone.

The zinc anomalies above the section are clearly indicative of the deep fault zone. They are caused by the location of sphalerite ( $\mathrm{ZnS}$ ) manifestations nearby. At the same level, strontium anomalies are more closely related to the Proterozoic marble distribution and are associated with the location of antimony. Firstly, this may be ascribed to celestine $\left(\mathrm{SrSO}_{4}\right)$ mineralization, which is associated with barite $\left(\mathrm{BaSO}_{4}\right)$, and the second is an isomorphic $\mathrm{Sb}$ impurity in arsenopyrite (FeAsS), which replaces arsenic.

The germanium enrichment zone is located in the north of the section. This is an isomorphic impurity in the sphalerite structure. This zone is located at the same stratigraphic level as the zinc anomaly in the central and southern blocks of the ore occurrence. 
The distribution of geochemical zoning generally corresponds to the previously established deposits of hydrothermal origin in the world. There is variability in the composition of ores on either side of the Breibogen fault zone with increasing distance away from the main ore occurrence. The northern block differs in the structure of anomalies from the central and southern blocks by a typical sub-ore association: bismuth, cobalt, and Nickel.

In the history of tectonic events in the area of the Sigurd ore occurrence, there were numerous movements of individual blocks up to the formation of brecciated zones and areas of intersection of ore veins.

Therefore, the northern block may well have experienced a relative uplift so that the zone of chalcocite mineralization from the lower level was displaced along with the block of the Devonian sandstones to the level of the main ore zone of the central block.

Secondly, and most likely reason for the concentration of bismuth, cobalt, and nickel in the northern block of the lower Devonian deposit in the Kap-Kyeldsen is related to the propylitization process, during which $\mathrm{Ni}$ and $\mathrm{Co}$ are part of the first stage of pyrite formation. Its secretions at a late stage are xenomorphic in nature and to a lesser extent contain impurity elements.

The southern and central blocks are characterized by auras of distribution of very similar ore elements: $\mathrm{Ag}-\mathrm{Pb}-\mathrm{Zn}-\mathrm{Cu}$, while the upper part of the section is enriched with lead, barium, and arsenic minerals.

\section{Source of ore substance}

One of the most controversial issues in hydrothermal ore formation is the problem of the source of ore elements. Previously we considered the source of copper and silver, as well as lead, zinc, and other elements to be contained in terrigenous strata of Devonian age [1]. However, later studies $[2,3]$ demonstrate the probability of Precambrian sources of ore elements, which are widely manifested in the points of mineralization of metamorphic rocks of the crystalline base.

Chemical analyses of the primary ore substance of the Sigurd ore occurrence, represented mainly by fahlore ores and chalcopyrite, were used to solve this problem. Minor ore minerals are: Galena, sphalerite, barite, associated with calcite and quartz. Secondary minerals are widely represented by malachite and azurite, as shown in Figure 5. As potential sources of ore matter, data on the chemical and microelement composition of red and gray sandstones and siltstones of the Lower Devonian, ore-bearing marble of metamorphic rocks of the Kollerbreen suite of Riphean age, and polymetallic ore occurrences of in other areas of the archipelago were used [3].

The test results show that the contents of the main ore and accompanying elements $\mathrm{Ag}, \mathrm{Cu}, \mathrm{As}$, $\mathrm{Sr}, \mathrm{Ba}, \mathrm{Ti}, \mathrm{Cr}, \mathrm{Co}, \mathrm{Ni}, \mathrm{Mo}, \mathrm{Sn}, \mathrm{Pb}, \mathrm{Zn}$ ) and their host rocks were counted; their mean number and correlation analysis for studying potential sources of ore matter were performed. The result is shown in Table 1.

The maximum value of the correlation coefficient between the compositions of the ore substance of the Sigurd ore occurrence is 0.90 with the composition of Proterozoic marble enriched with ore minerals. The second highest degree of correlation is reflected by limestone in the Lower Devonian Kap-Kyeldsen suite (0.80). Devonian conglomerates and green sandstones correlate in structure

Table 1: Results of the correlation analysis of geochemical features of ore substance with his potential sources in the containing rocks.

\begin{tabular}{|c|c|c|c|c|c|c|}
\hline \multirow[t]{2}{*}{ Name of Rocks } & \multirow{2}{*}{$\begin{array}{l}\text { Number } \\
\text { of Tests }\end{array}$} & \multicolumn{5}{|c|}{ Correlation Coefficient } \\
\hline & & $\begin{array}{l}\text { Sigurd - ore } \\
\text { substance }\end{array}$ & $\begin{array}{l}\text { Limestone } \\
\mathrm{D}_{1} \mathrm{kk}\end{array}$ & $\begin{array}{l}\text { Sandstone } \\
\text { green } D_{1} r b\end{array}$ & $\begin{array}{l}\text { Conglomerate } \\
\mathrm{D}_{1} \mathrm{rb}\end{array}$ & $\begin{array}{l}\text { Marble with the } \\
\text { ore substance } \mathrm{Pr}_{2}\end{array}$ \\
\hline Sigurd - ore substance & 31 & 1 & & & & \\
\hline Limestone $\mathrm{D}_{1} \mathrm{kk}$ & 33 & 0.80 & 1 & & & \\
\hline Sandstone green $\mathrm{D}_{1} \mathrm{rb}$ & 28 & 0.66 & 0.95 & 1 & & \\
\hline Conglomerate $D_{1} r b$ & 10 & 0.69 & 0.97 & 0.99 & 1 & \\
\hline $\begin{array}{l}\text { Marble with the ore } \\
\text { substance } \operatorname{Pr}_{2}\end{array}$ & 15 & 0.90 & 0.49 & 0.32 & 0.34 & 1 \\
\hline
\end{tabular}


with the ore substance to a lesser extent -0.66 and 0.69 than the carbonate layer for which mineralization is dated.

\section{Conclusion}

In the process of correlation analysis, the main influence on the result is not the absolute values of the element contents, but their ratio values. Of particular note are the concentrations of $\mathrm{Sr}, \mathrm{Ba}$, and $\mathrm{Ti}$, which increase in the listed order in all the studied samples. High titanium content is due to minerals such as rutile, anatase, sphene, and leucoxene, which are present in the heavy fraction even in Proterozoic carbonates and Devonian strata. Sr and $\mathrm{Ba}$ are part of the minerals that fills fractures and also permeate all deposits, calcite-barite with celestine veins.

Minimal correlation coefficients between Proterozoic marble compositions and Devonian conglomerates and green sandstones, suggests that their formation occurred not only and not so much due to the tectonism of nearby Riphean metamorphisms.

Complicating the reconstruction of the history of the formation of the Sigurd deposits are factors that must be taken into account: 1 - The probable process of multi-stage ore formation and 2- The influence of geochemical features of each of the elements under consideration on the dynamics of ore migration.

One of the features was the detection of free gold in Sigurd ore occurrences. It is determined by the atomic adsorption method in test XII/-42-6 in the amount of $0.36 \mathrm{~g} / \mathrm{t}$. The presence of gold was confirmed by the study of a polished sections; the sample contained $540 / 3$ grains of gold, $0.015 \mathrm{~mm}$ in size, in association with bornite, tennantite, chalcocite, chalcopyrite, and indigo copper. A $0.4 \mathrm{~mm}$ grain of free gold is found in the $\mathrm{VII} / 36$ polished slide along with a rich chalcopyrite-tennantite-chalcocite-indigo copper ore in the quartz-carbon portion. It is interesting to note that 6 small grains (about $0.01 \mathrm{~mm}$ ) diagnosed as küstelite (Ag18Au - Ag2.5Au) were found in a similar association in sample XII/-40-2. Given these facts, it seems that the Sigurd ore occurrence may also have a gold mineralization. Justification of this conclusion will require grouting sampling operations over the entire area of the ore occurrence.

Based on the above, we can conclude that the preferred similarity of geochemical associations of the Sigurd ore occurrence with the nearby late
Proterozoic marble is the first probable source of ore matter. The second source is more likely to be related to carbonate interlayers in the early Devonian strata. The circulation of ore-bearing solutions along the deep Breibogen faults zone frequently occurred and probably ended at the border of the Devonian and Carboniferous periods. This occurred during the period of tectonic-magmatic activity in the archipelago, which was expressed by the formation of alkaline and ultramafic igneous-dyke intrusions (age $D_{3}-C_{1}$ ).

\section{References}

1. Evdokimov AN (1990) A new ore-occurence of copper on Spitsbergen. Reports of Academy of Sciences of the USSR 314: 915-918.

2. VD Kaminsky, VI Ushakov, VD Kryukov (2010) Solid minerals of archipelagoes and islands of the Arctic continental suburb of Eurasia. Vniiokeangeologiya, $\mathrm{SPb}$., 7-64.

3. Sirotkin AN (2006) Problems metal geniuses and prospects of a ore-bearing of the Central Spitsbergen polymetallic area. Geologic-geophysical characteristics of a litosphere of the Arctic region. Vniiokeangeologiya, SPb., 241-254.

4. Evdokimov AN (2000) Volcanoes of Spitsbergen/SPb. Vniiokeangeologiya, Prod., 123.

5. Flood B (1967) Sulphide mineralization within the Hecla Hoek Complex in Westspitsbergen and Bjørnøya. Norsk Polarinstitutt. Årbok 1967, 109-129.

6. Segalstad TV (2006) Stable isotope evidence for $\mathrm{Ba}-\mathrm{Pb}-\mathrm{Zn}$ vein mineralizations by fluid circulation in the sedimentary basin at Svalbard. In: Segalstad TV, Sundblad K, Kjærnet T, Geological Survey of Finland Bulletin, 143.

7. Sundblad K (2006) Source of lead in Mesozoic baryte-galena-sphalerite mineralization at Svalbard. In: Sundblad K, Andersen T, Kjærnet T, Segalstad TV, Aasum L, et al. Geological Survey of Finland Bulletin, 157.

8. Hjelle A (1962) Contribution to the geology of the Hecla Hoek formation in Nordenskjold Land. Vestspitsbergen. Norsk Polar-institutt, Arbok 1961, Oslo, 83-95.

9. Smirnov SS (1946) Some common questions of studying of ore fields. News of Academy of Sciences of the USSR, geol 5: 17-34.

10.Emmons WH (1937) Gold deposits of the World. McGraw - Hill Book Company, New York, London, 562.

11. Evdokimov AN (2013) Late Paleozoic alkaline and ultramaphic magmatism Svalbard archipelago. In: Evdokimov AN, Sirotkin AN, Chebayevsky VS, Notes of mining institute, 201-209. 